\title{
Jaringan Saraf Radial Basis Probabilistic Untuk Identifikasi Morfologi Benih Padi Rawa Kalimantan Selatan
}

\author{
Radial Basis Probabilistic Neural Networks for Swamp Rice Seed \\ Morphology Identification in South Kalimantan
}

\author{
ONI SOESANTO ${ }^{1 *}$, AKHMAD YUSUF $^{1}$, DINDIN H. MURSYIDIN ${ }^{2}$, M. SYAHID \\ PEBRIADI $^{3}$
}

\begin{abstract}
Abstrak
Machine vision berbasis jaringan saraf tiruan dan pemrosesan gambar digital merupakan metode alternatif yang dapat dilakukan untuk mengidentifikasi dan mengevaluasi keragaman varietas padi. Berbeda dengan metode pengamatan langsung yang memiliki tingkat subjektivitas tinggi dan metode kimiawi (PCR) yang bersifat destruktif dan mahal, machine vision berbasis jaringan saraf tiruan menawarkan sistem identifikasi dan evaluasi secara cepat, praktis, murah, akurat, serta bersifat non-destruktif. Paper ini membahas machine vision berbasis jaringan saraf tiruan sebagai teknologi alternatif untuk identifikasi varietas padi rawa Kalimantan Selatan berdasarkan ciri morfologinya, yaitu area, perimeter, major axis, minor axis, circularity, aspect ratio, roundness, dan feret untuk setiap sampel benih padi. Dalam paper ini, sistem identifikasi varietas benih padi menggunakan jaringan saraf radial basis probabilistic dengan optimalisasi bobot hidden center menggunakan algoritme orthogonal least square. Dari proses learning dihasilkan performa pelatihan sebesar $88.32 \%$ dan performa pengujian sebesar $88.21 \%$ dengan tingkat keberhasilan pada proses pelatihan dari masing-masing varietas bayar papuyu, bayar putih, benih kuning, benih putih, ketan, siam gadis, siam unus, dan karan dukuh masing-masing sebesar $100 \%, 92.59 \%, 88.89 \%, 92.59 \%, 92.59 \%, 81.48 \%, 100.00 \%$, dan $100.00 \%$. Untuk proses pengujian, tingkat keberhasilan masing-masing varietas ialah $100.00 \%, 87.50 \%, 88.89 \%, 100.00 \%, 88.89 \%, 88.89 \%$, $100.00 \%$, dan $100.00 \%$.
\end{abstract}

Kata Kunci: benih padi, machine vision, morfologi, RBP-OLS

\begin{abstract}
Machine vision-based on neural network and digital image processing is an alternative method that can used to identify and evaluate the diversity of rice varieties. In contrast to the direct observation method which has a high degree of subjectivity and chemical methods (i.e. PCR) which is destructive and expensive, machine visionbased neural network identification and evaluation system offers quick, practical, inexpensive, accurate, and nondestructive approach. This paper discusses machine vision-based on neural network as an alternative technology for the identification of South Kalimantan swamp rice varieties based on morphologic characteristics, i.e. the area, perimeter, major axis, minor axis, circularity, aspect ratio, roundness, and feret for each rice seed samples. In this paper, rice seed varieties are identified using radial basis probabilistic neural network with hidden weight optimization algorithm centers using orthogonal least squares. The learning process gives performance of $88.32 \%$ training and testing performance of $88.21 \%$ with a success rate in the training process of each variety bayar papuyu, bayar putih, benih kuning, benih putih, ketan, siam gadis, siam unus, and karan dukuh each -masing of $100 \%, 92.59 \%, 88.89 \%, 92.59 \%, 92.59 \%, 81.48 \%, 100.00 \%$ and $100.00 \%$. For the testing process, the success rate of each variety is $100.00 \%, 87.50 \%, 88.89 \%, 100.00 \%, 88.89 \%, 88.89 \%, 100.00 \%$ and $100.00 \%$.
\end{abstract}

Keywords: machine vision, morphology, RBP-OLS, rice seed

\footnotetext{
${ }^{1}$ Departemen Matematika FMIPA Universitas Lambung Mangkurat

${ }^{2}$ Departemen Biologi FMIPA Universitas Lambung Mangkurat

${ }^{3}$ Mahasiswa Program Studi Ilmu Komputer FMIPA Universitas Lambung Mangkurat

*Penulis Korespondensi: Tel: 081348424284; Surel: oni.soesanto@gmail.com
} 


\section{PENDAHULUAN}

Koleksi benih padi (Oriza sativa L.) di seluruh dunia termasuk Indonesia merupakan sumber daya genetik esensial dalam program ketahanan pangan. Hal ini terjadi karena padi merupakan tanaman pangan terpopuler yang menjadi bahan makanan pokok bagi lebih dari setengah penduduk dunia (Zeng et al. 2010). Di samping itu, koleksi benih padi yang ada merupakan modal dasar yang sangat berharga dalam program pemuliaan dan pelestarian plasma nutfah. Lestari (2009), menyatakan bahwa sampai saat ini tidak kurang dari 400 ribu varietas padi disimpan sebagai koleksi plasma nutfah di seluruh dunia dan lebih dari 4000 varietas padi tersimpan di bank gen Balai Besar Biogen, Departemen Pertanian Republik Indonesia.

Identifikasi dan evaluasi terhadap koleksi plasma nutfah padi terutama di Indonesia merupakan kegiatan yang sangat penting dilakukan. Menurut Herrera et al. (2008), kegiatan identifikasi dan evaluasi terhadap koleksi dan keragaman genetik varietas padi merupakan kunci sukses program pemuliaan dan pelestarian plasma nutfah. Di sisi lain, ukuran dan bentuk padi yang meliputi warna, tekstur, dan kandungan air merupakan indikator penting untuk menentukan kualitas benih padi. Oleh karena itu, labelisasi berbagai varietas padi yang ada merupakan faktor penting yang dapat menentukan kualitas rasa nasi dan mutu tanak, karakteristik genetik dan agronomi, serta nilai komersial dari benih tersebut.

Akan tetapi, identifikasi dan evaluasi terhadap koleksi atau ragam varietas padi merupakan kegiatan yang sangat kompleks dan relatif sulit dilakukan (Guzman and Peralta 2008). Hal ini dikarenakan sistem identifikasi varietas padi umumnya hanya didasarkan pada pengamatan secara langsung terhadap karakter morfologi dan agronomi (hasil panen), serta metode kimiawi yang memiliki banyak kelemahan dan keterbatasan. Sebagai contoh, pengamatan langsung terhadap karakter morfologi dan agronomi (hasil panen) memiliki tingkat akurasi yang rendah dan memerlukan waktu yang relatif lama. Sementara itu, metode kimiawi memerlukan biaya yang mahal dan jumlah sampel yang relatif banyak, serta bersifat destruktif (Liu et al. 2005).

Machine vision berbasis jaringan saraf tiruan dan pemrosesan gambar digital merupakan metode alternatif yang dapat dilakukan untuk mengidentifikasi dan mengevaluasi keragaman varietas padi. Teknologi ini menawarkan sistem identifikasi dan evaluasi secara cepat, praktis, murah, akurat, serta bersifat non-destruktif. Machine vision berbasis jaringan saraf tiruan dan teknologi pemrosesan gambar digital telah diaplikasikan untuk identifikasi dan evaluasi keragaman genetik beberapa tanaman serealia, termasuk padi. Guzman and Peralta (2008) memperlihatkan bahwa sistem identifikasi mengunakan multi-layer percetron mampu mengklasifikasi ragam varietas padi yang ada di Filipina dengan akurasi sebesar 70 persen. Liu et al. (2005) menggunakan backpropagation dengan akurasi sebesar 74-95\%.

Teknik ini juga mempunyai keuntungan dan keunggulan untuk mengidentifikasi dan mengevaluasi keragaman varietas terutama sebagai basis data pendukung upaya pemuliaan dan pelestarian plasma nutfah padi yang ada di Indonesia, pembentukan core collection plasma nutfah padi di Indonesia, serta penguatan basis industri benih padi di Indonesia. Tulisan ini membahas machine vision berbasis jaringan saraf tiruan sebagai teknologi alternatif untuk identifikasi varietas padi rawa Kalimantan Selatan berdasarkan ciri morfologinya, yaitu area, perimeter, major axis, minor axis, circularity, aspect ratio, roundness, dan feret untuk setiap sampel benih padi. Sistem identifikasi menggunakan jaringan saraf radial basis probabilistic dengan optimalisasi bobot hidden center menggunakan orthogonal least square algorithm.

\section{METODE}

\section{Akuisisi Citra dan Sistem Pemroses Citra}

Citra digital diakuisisi menggunakan kamera digital Sony Cyber-shot Carl Zeiss 12.1 MP dengan citra digital benih padi untuk 8 varietas (Gambar 1). Citra berukuran 480x480 piksel. Jarak lensa kamera dengan objek diatur sejauh $10 \mathrm{~cm}$. Pencahayaan menggunakan 2 buah lampu Philips 8 watt. Sistem pemroses citra dibangun menggunakan Java-NetBeans 7.3.1, Java 
Development Kit Versi 7, basis data MySQL, dan XAMPP. Masukan sistem berupa citra digital benih padi dengan format JPEG dengan proses pengolahan citra meliputi ekualisasi histogram, pengubahan ke citra keabuan, segmentasi citra, serta binerisasi.

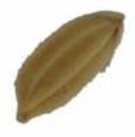

Bayar Papuyu

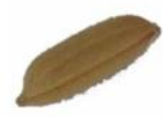

Bayar Putih

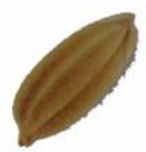

Benih Kuning

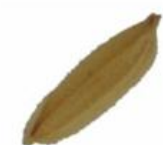

Benih Putih

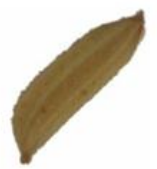

Ketan

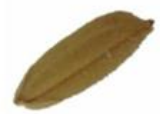

Siam Gadis

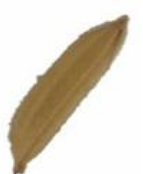

Siam Unus

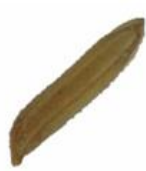

Karan Dukuh

Gambar 1 Benih dari 8 varietas padi rawa yang digunakan dalam penelitian

\section{Ekstraksi Fitur Morfologi}

Analisis bentuk digunakan untuk mengektraksi ciri setiap sampel benih padi. Ciri yang diekstraksi meliputi area, perimeter, shape factor, dan roundness. Area dan perimeter dihitung menggunakan metode kode rantai (chain code) yang sering digunakan untuk mendeskripsikan atau mengkodekan bentuk (kontur) suatu objek. Pembentukan kode rantai dimulai dengan menentukan piksel pertama dari objek. Berdasarkan piksel tersebut, kode rantai objek dibentuk dengan mengikuti aturan kode rantai. Berdasarkan kode rantainya, analisis terhadap suatu objek dapat dilakukan dengan menghitung area, perimeter, dan shape factor.

Kontur suatu objek, selain menggunakan kode rantai untuk, juga dapat dideskripsikan menggunakan metode region properties dengan pendekatan bentuk elips (Gambar 2). Setiap objek memiliki major axis length dan minor axis length. Nilai major axis length adalah jarak terjauh antara centroid dengan koordinat pixel terluar. Sementara itu, minor axis length adalah jarak antara centroid dengan koordinat pixel terdekat (Soemantri 2010).

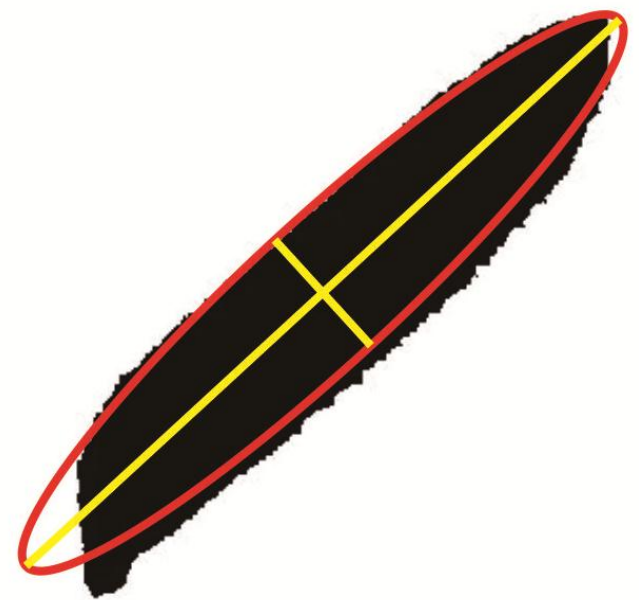

Gambar 2 Representasi region dengan bentuk elips

\section{Jaringan Syaraf Tiruan Radial Basis Probabilistic}

Proses identifikasi (Gambar 3) dilakukan menggunakan jaringan saraf tiruan RBP. RBP merupakan penggabungan model radial basis function (RBF) dan probabilistic neural network (PNN) berdasarkan keunggulan masing-masing dari dua model tersebut. RBF melibatkan dimensi tinggi pada lapisan tersembunyi dan neuron tersembunyi yang tak linier. Akan tetapi, metode ini memiliki struktur yang rumit. Di lain pihak, PNN mempunyai kemampuan klasifikasi yang secara langsung bisa dicapai tanpa melatih vektor bobot. Akan tetapi, PNN tidak mempertimbangkan lingkungan dan tumpang tindih antara vektor-vektor data latih dari kategori yang berbeda sehingga berakibat bias. Selain itu, PNN menggunakan semua vektor data latih sebagai center pada lapisan tersembunyi yang menjadi sangat rumit saat PNN diterapkan pada data latih berukuran besar sehingga performanya menjadi lambat. Untungnya, 
kelemahan PNN ini bisa diatasi oleh RBF dengan menyelesaikan permasalahan pertama pada PNN dan mengoptimalkan permasalahan kedua (Huang dan Du 2008).

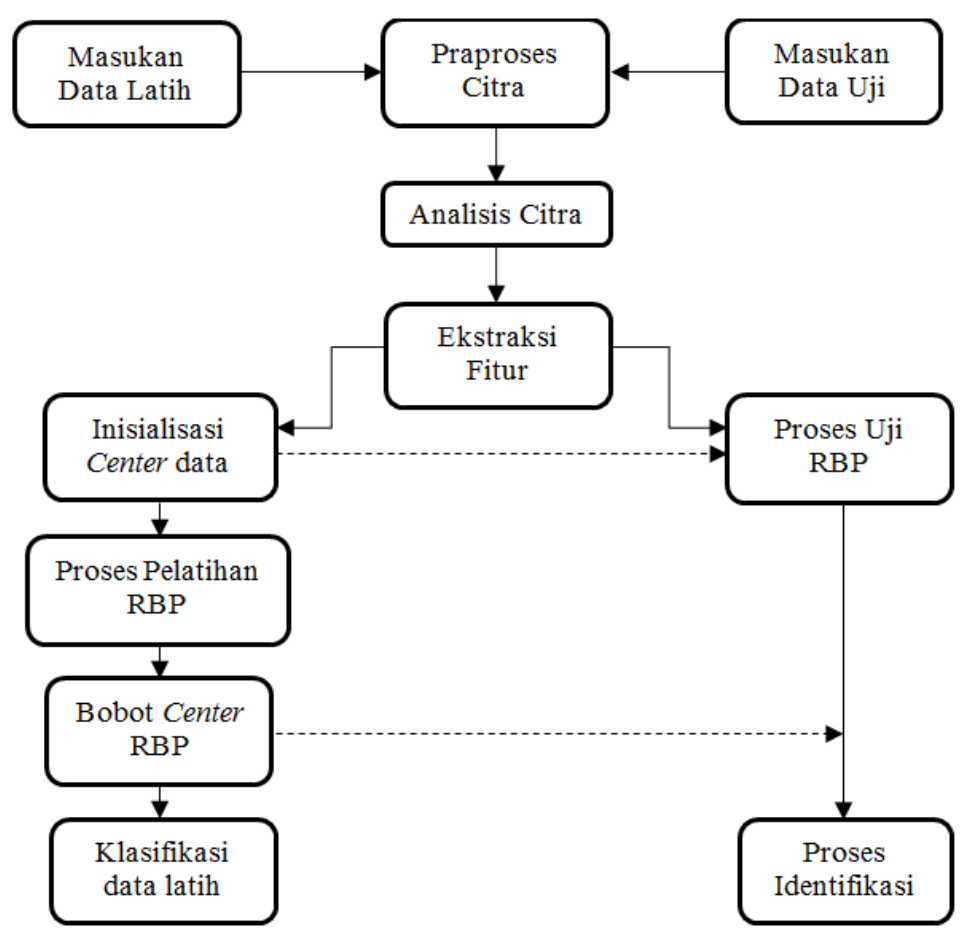

Gambar 3 Diagram proses identifikasi

Penentuan center RBF-PNN mengikuti model pemilihan center pada PNN, yaitu dengan menggunakan semua data latih sebagai center. Penentuan center dengan metode ini tentunya tidak efisien dan mengurangi tingkat kemampuan jaringan. Beberapa metode optimalisasi bobot center dan penyederhanaan arsitektur jaringan saraf yang telah dikembangkan adalah algoritme OLS (Huang et al. 2005), recursive orthogonal least square (ROLS) (Huang dan Du 2008), dan gradient descent (Hasanudin dan Irawan 2009).

Secara matematis, RBP dengan vektor masukan $x$ akan menghasilkan nilai aktual untuk neuron keluaran ke-i $y_{i}^{\alpha}$ yang dinyatakan sebagai persamaan 1 (Huang dan Du 2008).

$$
y_{i}^{\alpha}=\sum_{k=1}^{M} w_{i k} h_{k}(x)
$$

Dengan

$$
h_{k}(x)=\sum_{i=1}^{n k} \varphi_{i}\left(x, c_{k i}\right)=\sum_{i=1}^{n k} \varphi_{i}\left(\left\|x-c_{k i}\right\|_{2}\right), k=1,2, . ., M
$$

Metode penentuan inisialisasi center untuk RBF dapat juga dilakukan pada RBP. Salah satu metode yang digunakan untuk menentukan inisialisasi center RBF ialah dengan menggunakan teknik clustering. Misalkan terdapat sampel pelatihan sebanyak $N$, matriks keluaran jaringan RBP $Y \in R^{n r \times m}$ dapat dituliskan $[Y(1), Y(2), \ldots, Y(N)]^{\mathrm{T}} \in R^{n r \times m}$ atau $Y=[Y(t$ 1) $y(t)]^{\mathrm{T}}$. Matriks keluaran pada lapisan tersembunyi kedua $H \in R^{n r \times m}$ dapat dituliskan seperti pada persamaan 3:

$$
H(t)=\left[h_{1}(i), h_{2}(i), \ldots, h_{m}(i)\right]^{\mathrm{T}} \in R^{n r \times m} \operatorname{atau}_{\mathrm{j}}(\mathrm{i})=\sum_{\mathrm{k}=1}^{\mathrm{ck}} \varphi_{\mathrm{jk}}(\mathrm{i}), \mathrm{j}=1,2, \ldots, \mathrm{m}, \mathrm{i}=1,2, \ldots, \mathrm{N}
$$


Bobot $W \in R^{m r \times m}$ dapat dituliskan $[w(1), w(2), \ldots, w(m)] \in R^{m r \times m}$. Keluaran yang diinginkan pada lapisan tersembunyi kedua dapat ditulis sebagai

$$
Y(i)=\left[y_{1}(i) ; y_{2}(i), \ldots, y_{m}(i)\right]^{T}, i=1,2, \ldots N
$$

$H$ mengacu pada fungsi kernel $\phi_{j k}$ ke- $k$ yang berhubungan dengan kelas ke-j pada lapisan tersembunyi pertama, dan $y_{j}(i)$ ke keluaran ke- $j$ yang diinginkan berhubungan dengan sampel latihan ke- $i$.

Secara umum, bobot keluaran pada jaringan feedforward didasarkan pada fungsi biaya galat atau mengacu pada fungsi targetnya, yaitu fungsi pada struktur jaringan dan bobot. Untuk RBP, galat pada fungsi biaya didefinisikan pada persamaan 5 (Huang et al. 2005).

$$
J(W)=\|Y-H W\|_{F}^{2}
$$

\|\|$_{\mathrm{F}}^{2}$ adalah norm Frobenius, $Y$ matriks keluaran, $H$ matriks keluaran pada lapisan tersembunyi, dan $W$ adalah matriks bobot antara lapisan tersembunyi dan lapisan keluaran.

Dengan mennggunakan dekomposisi ortogonal, matriks $H$ pada persamaan (5) merupakan matriks berukuran $M \times N$ dengan vektor kolom bebas linier, $Q$ adalah matriks ortogonal berukuran $N \times N$ yang memenuhi $Q \times Q^{T}=Q^{T} \times Q=I, R$ adalah matriks segitiga atas berukuran $M \times M$. Karena $\mathrm{Q}$ matriks orthogonal, diperoleh

$$
Y=Q\left[\begin{array}{l}
\hat{Y} \\
\tilde{Y}
\end{array}\right]
$$

Berdasarkan transformasi ortogonal, diperoleh fungsi biaya sebagai berikut

$$
J(W)=\|\hat{Y}-H W\|_{F}^{2}+\|\tilde{Y}\|_{F}^{2}
$$

Selanjutnya, bobot $W=R^{-1} \hat{Y}$ diperoleh dengan meminimumkan fungsi galat $J(W)$.

\section{HASIL DAN PEMBAHASAN}

Data yang digunakan dalam penelitian ini adalah benih padi 8 varietas lokal Kalimantan Selatan yang diambil dari Balittra (Balai Penelitian Lahan Rawa), yaitu bayar papuyu, bayar putih, benih kuning, benih putih, ketan, siam gadis, siam unus, dan karan dukuh (Balittra 2011). Sebanyak 7 ciri sampel citra digital diekstraksi, meliputi area, perimeter, major axis, minor axis, circularity, aspect ratio, roundness, dan feret. Citra digital yang dijadikan data uji coba terdiri atas 288 data. Sebanyak 216 citra digunakan sebagai data latih dan 72 citra sebagai data uji. Tabel 1 menampilkan hasil proses ekstraksi fitur setiap citra benih. Proses ekstraksi dilakukan dengan menggunakan perangkat lunak yang disajikan pada Gambar 3.

Jaringan RBP terdiri atas 4 lapisan. Lapisan tersembunyi pertama merupakan proses non linear untuk center terpilih dari data latih. Lapisan tersembunyi kedua merupakan jumlah dari keluaran lapisan tersembunyi pertama. Penentuan center $c$ berukuran $n \times r$ dilakukan secara acak dan target cluster $T$ berukuran $m \times 1$ dan dijadikan inisialisasi masukan untuk RBP.

Untuk mengetahui performa pembelajaran pada jaringan saraf RBP-OLS, perhitungan dan simulasi pada proses klasifikasi data simulasi dilakukan. Performa hasil klasifikasi pada RBP-OLS dihitung dengan membandingkan banyaknya kesesuaian setiap data terhadap target masukan. Pada proses pengujian, jarak $\phi$ pada vektor masukan untuk pengujian dihitung guna mendapatkan matriks $H$ pada persamaan (5). Selanjutnya, matriks $H$ digunakan untuk mencari 
keluaran $Y$ dengan menggunakan bobot $W$ yang telah diperoleh pada proses pelatihan dari persamaan (5).

Tabel 1 Ekstraksi fitur morfologi

\begin{tabular}{|c|c|c|c|c|c|c|c|c|c|}
\hline No & Varietas & Area & $\begin{array}{c}\text { Peri } \\
\text { meter }\end{array}$ & Major Axis & Minor Axis & $\begin{array}{l}\text { Circu } \\
\text { larity }\end{array}$ & $\begin{array}{l}\text { Aspect } \\
\text { Ratio }\end{array}$ & $\begin{array}{c}\text { Roud } \\
\text { ness }\end{array}$ & Feret \\
\hline 1 & Bayar Papuyu & 21.088 & 20.219 & 8.022 & 3.347 & 0.648 & 2.397 & 0.417 & 8.453 \\
\hline 2 & Bayar Putih & 17.644 & 19.525 & 7.753 & 2.898 & 0.582 & 2.676 & 0.374 & 8.288 \\
\hline 3 & Benih Kuning & 23.853 & 21.508 & 8.430 & 3.603 & 0.648 & 2.340 & 0.427 & 8.972 \\
\hline 4 & Benih Putih & 22.066 & 22.307 & 8.883 & 3.163 & 0.557 & 2.808 & 0.356 & 9.409 \\
\hline 5 & Ketan & 19.354 & 22.288 & 9.337 & 2.639 & 0.490 & 3.537 & 0.283 & 9.704 \\
\hline 6 & Siam Gadis & 17.637 & 19.609 & 7.765 & 2.892 & 0.577 & 2.685 & 0.372 & 8.175 \\
\hline 7 & Siam Unus & 17.412 & 19.987 & 8.250 & 2.687 & 0.548 & 3.070 & 0.326 & 8.658 \\
\hline 8 & Karan Dukuh & 19.050 & 24.015 & 10.120 & 2.397 & 0.416 & 4.222 & 0.237 & 10.433 \\
\hline
\end{tabular}

Tabel 2 Performa proses pelatihan dan pengujian

\begin{tabular}{|c|c|c|c|c|c|c|c|c|c|}
\hline \multirow{2}{*}{$\begin{array}{l}\text { Hidden } \\
\text { Center }\end{array}$} & \multicolumn{2}{|c|}{ Performa } & \multicolumn{2}{|c|}{ CPU time } & \multirow{2}{*}{$\begin{array}{l}\text { Hidden } \\
\text { Center }\end{array}$} & \multicolumn{2}{|c|}{ Performa } & \multicolumn{2}{|c|}{ CPU time } \\
\hline & Latih $(\%)$ & $\begin{array}{l}\mathrm{Uji} \\
(\%)\end{array}$ & $\begin{array}{l}\text { Latih } \\
(\%)\end{array}$ & $\begin{array}{l}\mathrm{Uji} \\
(\%)\end{array}$ & & $\begin{array}{c}\text { Latih } \\
(\%)\end{array}$ & $\begin{array}{l}\mathrm{Uji} \\
(\%)\end{array}$ & $\begin{array}{c}\text { Latih } \\
(\%)\end{array}$ & $\mathrm{Uji}(\%)$ \\
\hline 8 & 57.6923 & 54.8387 & 0.0312 & 0.0156 & 120 & 92.3077 & 96.7742 & 0.1404 & 0.0312 \\
\hline 16 & 58.9744 & 51.6129 & 0.0156 & 0.0156 & 128 & 92.3077 & 90.3226 & 0.1560 & 0.0312 \\
\hline 24 & 67.9487 & 64.5161 & 0.0156 & 0.0156 & 136 & 92.3077 & 93.5484 & 0.1872 & 0.0312 \\
\hline 32 & 79.4872 & 80.6452 & 0.0312 & 0.0156 & 144 & 92.3077 & 90.3226 & 0.2808 & 0.0312 \\
\hline 40 & 85.8974 & 83.8710 & 0.0624 & 0.0312 & 152 & 92.3077 & 96.7742 & 0.1092 & 0.0312 \\
\hline 48 & 91.0256 & 96.7742 & 0.0624 & 0.0312 & 160 & 92.3077 & 87.0968 & 0.2184 & 0.0312 \\
\hline 56 & 89.7436 & 80.6452 & 0.0936 & 0.0312 & 168 & 92.3077 & 90.3226 & 0.2808 & 0.0624 \\
\hline 64 & 93.5897 & 93.5484 & 0.0780 & 0.0312 & 176 & 92.3077 & 90.3226 & 0.2808 & 0.0312 \\
\hline 72 & 91.0256 & 87.0968 & 0.0936 & 0.0312 & 184 & 92.3077 & 87.0968 & 0.1872 & 0.0312 \\
\hline 80 & 92.3077 & 90.3226 & 0.0936 & 0.0312 & 192 & 92.3077 & 90.3226 & 0.2496 & 0.0312 \\
\hline 88 & 92.3077 & 90.3226 & 0.1248 & 0.0312 & 200 & 92.3077 & 87.0968 & 0.3900 & 0.0312 \\
\hline 96 & 92.3077 & 90.3226 & 0.1872 & 0.0312 & 208 & 92.3077 & 93.5484 & 0.2496 & 0.0312 \\
\hline 104 & 92.3077 & 96.7742 & 0.1560 & 0.0312 & 216 & 92.3077 & 93.5484 & 0.1716 & 0.0312 \\
\hline 112 & 92.3077 & 90.3226 & 0.2184 & 0.0312 & 224 & 92.3077 & 80.6452 & 0.2340 & 0.0624 \\
\hline
\end{tabular}

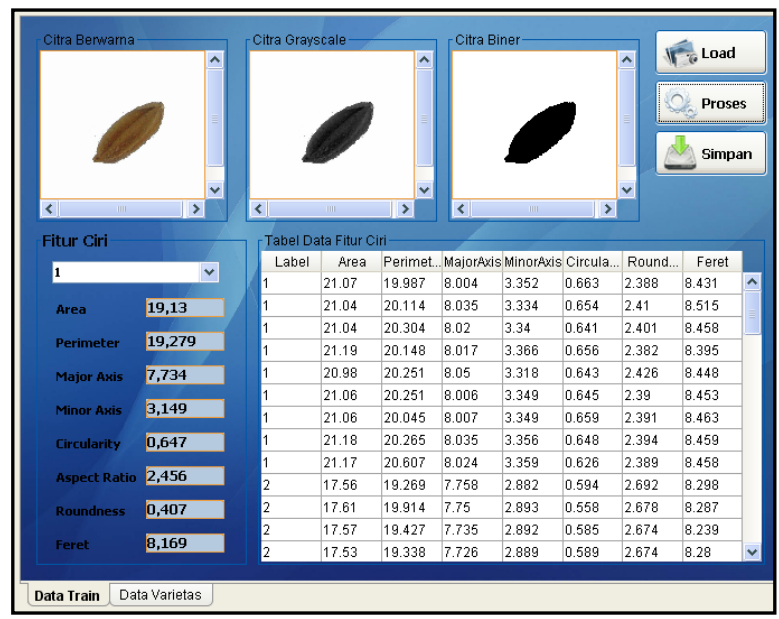

Gambar 4 Screenshot simulasi proses ekstraksi fitur

Fitur-fitur ciri digunakan sebagai input jaringan saraf tiruan RBF sebanyak 234 data sampel latih dan 72 sampel uji. Inisialisasi center dilakukan secara acak dengan beberapa kombinasi jumlah hidden center (Tabel 2). Data pada Tabel 2 menunjukkan bahwa proses pelatihan mencapai performa terbaik pada jumlah hidden center 104 dengan performa latih 93.31\% dengan waktu 0.156 detik dan performa pengujian $96.77 \%$ dengan waktu 0.0312 detik. Dari beberapa pengujian diperoleh rata-rata persentase performa pada proses pelatihan sebesar $88.33 \%$ dengan waktu rata-rata 0.1651 detik. Sementara itu, proses identifikasi (pengujian) terhadap citra benih padi memperoleh persentase keberhasilan $88.21 \%$ dengan waktu rata-rata 
0.0280 detik. Secara ringkas performa selama proses pelatihan dan pengujian dapat dilihat pada Gambar 5 dan Gambar 6.

Dari uji coba dengan 104 hidden center didapat sebanyak 18 data yang salah diidentifikasi, sedangkan pada proses pengujian terdapat 5 data yang teridentifikasi salah. Tingkat keberhasilan pada proses pelatihan dari masing-masing varietas bayar papuyu, bayar putih, benih kuning, benih putih, ketan, siam gadis, siam unus, dan karan dukuh masing-masing sebesar $100.00 \%, 92.59 \%, 88.89 \%, 92.59 \%, 92.59 \%, 81.48 \%, 100.00 \%$, dan $100.00 \%$.

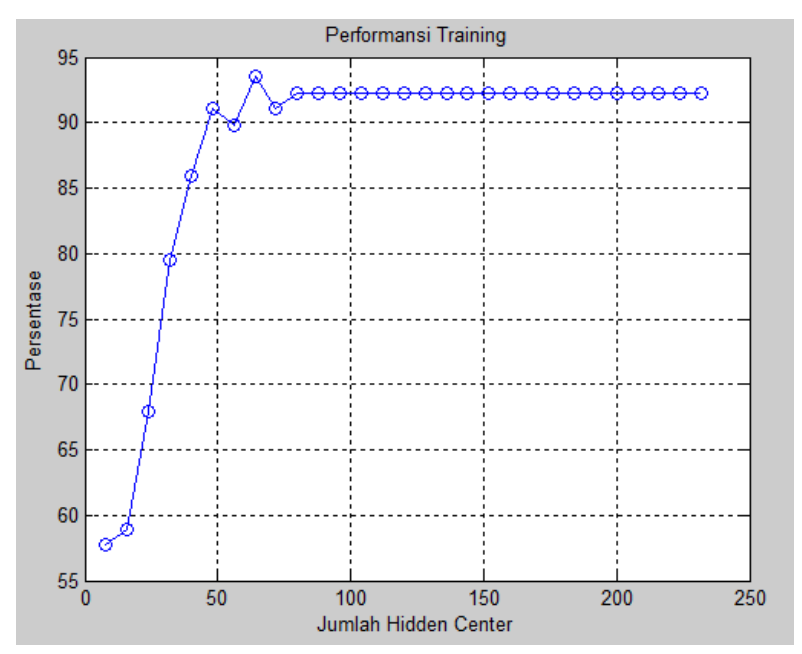

Gambar 5 Performa pelatihan

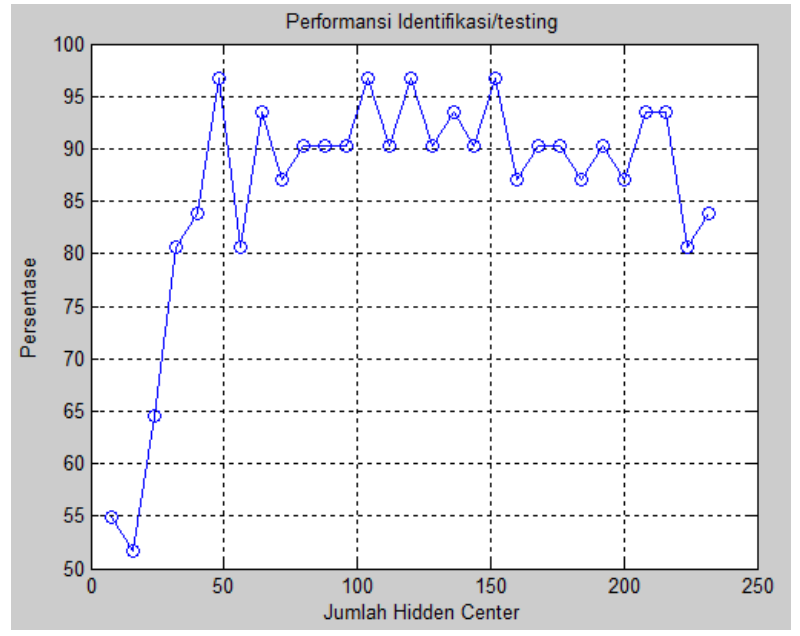

Gambar 6 Performa pengujian

Tabel 3 Confusion matrix pada proses pelatihan

\begin{tabular}{lccccccccr}
\hline \multirow{2}{*}{ Kelas Aktual } & \multicolumn{8}{c}{ Kelas Prediksi } \\
\cline { 2 - 8 } & $\begin{array}{c}\text { Bayar } \\
\text { Papuyu }\end{array}$ & $\begin{array}{c}\text { Bayar } \\
\text { Putih }\end{array}$ & $\begin{array}{c}\text { Benih } \\
\text { Kuning }\end{array}$ & $\begin{array}{c}\text { Benih } \\
\text { Putih }\end{array}$ & Ketan & $\begin{array}{c}\text { Siam } \\
\text { Gadis }\end{array}$ & $\begin{array}{c}\text { Siam } \\
\text { Unus }\end{array}$ & $\begin{array}{c}\text { Karan } \\
\text { Dukuh }\end{array}$ \\
\hline Bayar Papuyu & 27 & 0 & 0 & 0 & 0 & 0 & 0 & 0 & 100.00 \\
Bayar Putih & 0 & 25 & 0 & 0 & 0 & 2 & 0 & 0 & 92.59 \\
Benih Kuning & 0 & 0 & 24 & 0 & 0 & 3 & 0 & 0 & 88.89 \\
Benih Putih & 0 & 2 & 0 & 25 & 0 & 0 & 0 & 0 & 92.59 \\
Ketan & 0 & 0 & 0 & 0 & 25 & 0 & 2 & 0 & 92.59 \\
Siam Gadis & 3 & 2 & 0 & 0 & 0 & 22 & 0 & 0 & 81.48 \\
Siam Unus & 0 & 0 & 0 & 0 & 0 & 0 & 27 & 0 & 100.00 \\
Karan Dukuh & 0 & 0 & 0 & 0 & 0 & 0 & 0 & 27 & 100.00 \\
\hline
\end{tabular}

Tabel 4 Confusion matrix pada proses pengujian atau identifikasi

\begin{tabular}{|c|c|c|c|c|c|c|c|c|c|}
\hline \multirow[b]{2}{*}{ Kelas Aktual } & \multicolumn{8}{|c|}{ Kelas Prediksi } & \multirow{2}{*}{$\begin{array}{c}\% \\
\text { Benar }\end{array}$} \\
\hline & $\begin{array}{c}\text { Bayar } \\
\text { Papuyu }\end{array}$ & $\begin{array}{l}\text { Bayar } \\
\text { Putih }\end{array}$ & $\begin{array}{c}\text { Benih } \\
\text { Kuning }\end{array}$ & $\begin{array}{l}\text { Benih } \\
\text { Putih }\end{array}$ & Ketan & $\begin{array}{r}\text { Siam } \\
\text { Gadis }\end{array}$ & $\begin{array}{l}\text { Siam } \\
\text { Unus }\end{array}$ & $\begin{array}{l}\text { Karan } \\
\text { Dukuh }\end{array}$ & \\
\hline Bayar Papuyu & 9 & 0 & 0 & 0 & 0 & 0 & 0 & 0 & 100.00 \\
\hline Bayar Putih & 0 & 7 & 0 & 0 & 0 & 2 & 0 & 0 & 87.50 \\
\hline Benih Kuning & 0 & 0 & 8 & 0 & 0 & 1 & 0 & 0 & 88.89 \\
\hline Benih Putih & 0 & 0 & 0 & 9 & 0 & 0 & 0 & 0 & 100.00 \\
\hline Ketan & 0 & 0 & 0 & 0 & 8 & 0 & 1 & 0 & 88.89 \\
\hline Siam Gadis & 0 & 1 & 0 & 0 & 0 & 8 & 0 & 0 & 88.89 \\
\hline Siam Unus & 0 & 0 & 0 & 0 & 0 & 0 & 9 & 0 & 100.00 \\
\hline Karan Dukuh & 0 & 0 & 0 & 0 & 0 & 0 & 0 & 9 & 100.00 \\
\hline
\end{tabular}

Tingkat keberhasilan proses pengujian masing-masing varietas ialah $100.00 \%, 87.50 \%$, $88.89 \%, 100.00 \%, 88.89 \%, 88.89,100.00 \%$, dan $100.00 \%$. Performa klasifikasi pada proses pelatihan dan identifikasi pada proses pengujian untuk masing-masing varietas diberikan dalam Tabel 3 dan Tabel 4. Dari penjelasan di atas dapat dilihat bahwa identifikasi varietas benih padi menggunakan jaringan saraf tiruan RBP-OLS memiliki akurasi yang cukup baik dalam proses pelatihan berdasarkan ciri morfologinya. 


\section{SIMPULAN}

Hasil simulasi menunjukan bahwa proses pelatihan pada jaringan saraf tiruan RBP-OLS mencapai performa rata-rata $88.33 \%$ dengan waktu 0.1651 detik dan performa pengujian $88.21 \%$ dengan waktu 0.0280 detik. Tingkat keberhasilan pada proses pelatihan dari masingmasing varietas bayar papuyu, bayar putih, benih kuning, benih putih, ketan, siam gadis, siam unus, dan karan dukuh masing-masing sebesar 100.00\%, 92.59\%, 88.89\%, 92.59\%, 92.59\%, $81.48 \%, 100.00 \%$, dan $100.00 \%$. Tingkat keberhasilan masing-masing varietas pada proses pengujian ialah $100.00 \%, 87.50 \%, 88.89 \%, 100.00 \%, 88.89 \%, 88.89 \%, 100.00 \%$, dan $100.00 \%$. Dengan demikian, jaringan saraf tiruan radial basis probabilistic dengan optimalisasi bobot center menggunakan orthogonal least square memiliki performa yang cukup baik dalam mengidentifikasi varietas padi rawa Kalimantan Selatan berdasarkan ciri morfologinya, yaitu area, perimeter, major axis, minor axis, circularity, aspect ratio, roundness dan feret untuk setiap sampel benih padi.

\section{UCAPAN TERIMA KASIH}

Terima kasih penulis ucapkan kepada Balai Penelitian Pertanian Lahan Rawa (Balittra) Banjarbaru, Kalimantan Selatan.

\section{DAFTAR PUSTAKA}

[Balittra] Balai Penelitian Pertanian Lahan Rawa. 2011. Koleksi Varietas Padi Lokal Lahan Rawa Sumatera dan Kalimantan: Buku Panduan Loka Pekan Raya Lahan Rawa. Banjarbaru(ID): Balai Penelitian Pertanian Lahan Rawa.

Guzman JD, Peralta EK. 2008. Classification of Philippine rice grains using machine vision and artificial neural networks. Di dalam: IAALD AFITA WCCA, World Conference on Agricultural Information and IT. hlm 41-48.

Hasanuddin, Irawan IM. 2009. The study of sensitivity of radial basis probabilistic neural network. Di dalam: International Conference on Mathematics, Statistics, and Their Application. hlm 344-349.

Herrera TG, Duque DP, Almeida IP, GT. Núñez, AJ. Pieters, CP. Martinez, and JM. Tohme. 2008. Assessment of genetic diversity in Venezuelan rice cultivars using simple sequence repeats markers. Electronic Journal of Biotechnology 11(5):1-14.

Huang DS, Zao WB. 2005. Determining the center of radial basis probabilistic neural network by recursive orthogonal least square algorithms. Applied Mathematics and Computation 162:461-473.

Huang DS, Du JX. 2008. A constructive hybrid structure optimization methodology for radial basis probabilistic neural network. IEEE Transactions on Neural Network 19:2009-2115.

Lestari P. 2009. Metode PCR (Polymerase Chain Reaction), cara mengidentifikasi padi bermutu rasa tinggi. Bogor (ID): Balai Besar Penelitian dan Pengembangan Bioteknologi dan Sumberdaya Genetik Pertanian.

Liu ZY, Cheng F, Ying YB, Rao XQ. 2005. Identification of rice seed varieties using neural network. J Zhejiang Univ Sci B. 6(11):1095-1100.

Somantri AS. 2010. Menentukan klasifikasi mutu fisik beras dengan menggunakan teknologi pengolahan citra digital dan jaringan syaraf tiruan. Jurnal Standardisasi 12(3):162-173.

Walpole ER. 1992. Pengantar Statistika. Jakarta (ID): Gramedia. 